Letters

\section{Coagulation concerns in patients with COVID-19 proposed for regional anesthesia}

\section{To the Editor}

Recently, we published practice recommendations about regional anesthesia in patients with suspected or confirmed COVID-19. ${ }^{1}$ Many anesthesiogists have embraced regional anesthetic techniques during the COVID-19 crisis due it presumed physiological benefits as well as possible reductions in transmission risks. There may be some unique characteristics of the coagulation state of patients with COVID-19 that we thought merited a communication.

Mild thrombocytopenia is common in the affected population, but platelet count is rarely less than $100,000 / \mathrm{mL}^{2}$ Around $20 \%-55 \%$ of hospitalized patients for COVID-19 have laboratory evidence of coagulopathy, namely elevated D-dimer concentrations $(\geq 2$ times above normal range), mildly prolonged prothrombin time (1-3 s prolongation above normal range) and, in late disease, decreased fibrinogen levels $(<2 \mathrm{~g} / \mathrm{L}(5.88 \mu \mathrm{mol} / \mathrm{L})){ }^{2}$ Indeed, coagulopathy correlates with severity of disease. ${ }^{2}$ Therefore, preoperative platelet count and coagulation assays should be considered for all patients scheduled for neuraxial or profound blocks, with postoperative re-testing if a perineural catheter is used in the previous locations. ${ }^{1}$

A platelet count above $75,000 / \mathrm{mL}$ is an acceptable level for performing neuraxial techniques in obstetric patients. ${ }^{3}$ In select circumstances of obstetric anesthesia, platelet count between 50 and 80,000/ $\mathrm{mL}$ may still allow neuraxial block. ${ }^{3}$ The platelet count threshold for lumbar puncture is substantially below and the risk of spinal hematoma is very low in oncology patients. ${ }^{3}$ Since a thinner needle is used and no catheter is placed at the epidural space, the risk of spinal hematoma after spinal anesthesia seems to be lower than after epidural catheterization. ${ }^{3}$

When neuraxial procedure is considered desirable, thromboelastography may be useful in patients with worrisome thrombocytopenia. ${ }^{3}$ In these cases, the decision to proceed with spinal anesthesia is a balance between benefits and risks for the patient. ${ }^{3}$

COVID-19 coagulopathy seems to be prothrombotic. ${ }^{2}$ In the absence of a contraindication, inpatients infected with COVID-19 should receive thromboembolic prophylaxis, with some evidence supporting low molecular weight heparin for pregnant women with confirmed COVID-19 even at home. ${ }^{2}{ }^{4}$ Standard regional anesthesia precautions are in order for starting and stopping anti-coagulation. ${ }^{5}$

Angela Barbosa Mendes, ${ }^{1}$ Constança Penedos, ${ }_{1}$ Luísa Vaz Rodrigues, ${ }^{1}$ Joana Santos Varandas, ${ }^{1}$ Neusa Lages, ${ }^{1}$ Humberto Machado ${ }^{1,2}$

${ }^{1}$ Serviço de Anestesiologia, Centro Hospitalar Universitário do Porto EPE, Porto, Portugal

${ }^{2}$ Instituto de Ciências Biomédicas Abel Salazar, Universidade do Porto, Porto, Portugal

Correspondence to Angela Barbosa Mendes, Serviço de Anestesiologia, Centro Hospitalar Universitário do Porto EPE, Porto 4099-001, Portugal: angelaisabelmendes@hotmail.com

Contributors All authors discussed the topics included on this letter. All authors contributed to scientific rigor and writing of this work. NL and HM supervised the work.

Funding The authors have not declared a specific grant for this research from any funding agency in the public, commercial or not-for-profit sectors.

Competing interests None declared.

Patient consent for publication Not required.

Provenance and peer review Not commissioned; internally peer reviewed.

This article is made freely available for use in accordance with BMJ's website terms and conditions for the duration of the covid-19 pandemic or until otherwise determined by BMJ. You may use, download and print the article for any lawful, non-commercial purpose (including text and data mining) provided that all copyright notices and trade marks are retained.

(C) American Society of Regional Anesthesia \& Pain Medicine 2021. No commercial re-use. See rights and permissions. Published by BMJ.

\section{D) Check for updates}

To cite Mendes AB, Penedos $C$, Vaz Rodrigues $L$, et al. Reg Anesth Pain Med 2021;46:457.

Received 8 May 2020

Revised 12 May 2020

Accepted 14 May 2020

Published Online First 28 May 2020

Reg Anesth Pain Med 2021;46:457.

doi:10.1136/rapm-2020-101676

\section{REFERENCES}

1 Mendes AB, Penedos C, Rodrigues LV, et al. The role of locoregional anesthesia in the Covid-19 pandemic. Acta Médica Portuguesa 2020.

2 Lee SG, Fralick M, Sholzberg M. Coagulopathy associated with COVID-19. Can Med Assoc J 2020:cmaj. 200685

3 Ho AM-H, Mizubuti GB, Ho AK. Safety of spinal anesthesia in thrombocytopenic patients: are there lessons to be learnt from oncology? Reg Anesth Pain Med 2019:44:29-31.

4 Sociedad Española de Trombosis y Hemostasia. Recomendaciones de tromboprofilaxis y tratamiento antitrombótico en pacientes con COVID-19, 2020. Available: https://www.covid-19.seth.es/wp-content/ uploads/2020/04/Recomendaciones-tromboprofilaxis-ytratamiento-antitrombotico-pacientes-COVID-19_202004-29.pdf [Accessed 3 May 2020].

5 Horlocker TT, Vandermeuelen E, Kopp SL, et al. Regional anesthesia in the patient receiving antithrombotic or thrombolytic therapy: American Society of Regional
Anesthesia and Pain Medicine evidence-based guidelines (fourth edition). Reg Anesth Pain Med 2018;43:263-309 